\title{
Striatal Neurodegeneration that Mimics Huntington's Disease Modifies GABA-induced Currents
}

\author{
Jorge Flores-Hernández ${ }^{1}$, Jeanette A. Garzón-Vázquez ${ }^{1}$, Gustavo Hernández-Carballo ${ }^{1}$, \\ Elizabeth Nieto-Mendoza ${ }^{2}$, Evelyn A. Ruíz-Luna ${ }^{1}$ and Elizabeth Hernández-Echeagaray ${ }^{2, * \text { (D) }}$ \\ 1 Instituto de Fisiología, Benemérita Universidad Autónoma de Puebla, Puebla C.P.72570, México; \\ jlvflores@hotmail.com (J.F.-H.); jeanettegarzon@gmail.com (J.A.G.-V.); \\ l.gustavoh.carballo@gmail.com (G.H.-C.); evy_0927@hotmail.com (E.A.R.-L.) \\ 2 Laboratorio de neurofisiología del desarrollo y la neurodegeneración, UBIMED, FES-Iztacala, \\ Universidad Nacional Autónoma de México, México, FES-Iztacala, Av. de Los Barrios \#1, Los Reyes Iztacala, \\ Tlalnepantla C.P.54090, México; elynieto@gmail.com \\ * Correspondence: aehe67@gmail.com or elihernandez@unam.mx; Tel.: +52-55-5623-1333 (ext. 39787)
}

Received: 23 October 2018; Accepted: 4 December 2018; Published: 6 December 2018

\begin{abstract}
Huntington's Disease (HD) is a degenerative disease which produces cognitive and motor disturbances. Treatment with GABAergic agonists improves the behavior and activity of mitochondrial complexes in rodents treated with 3-nitropropionic acid to mimic HD symptomatology. Apparently, GABA receptors activity may protect striatal medium spiny neurons (MSNs) from excitotoxic damage. This study evaluates whether mitochondrial inhibition with 3-NP that mimics the early stages of HD, modifies the kinetics and pharmacology of GABA receptors in patch clamp recorded dissociated MSNs cells. The results show that MSNs from mice treated with 3-NP exhibited differences in GABA-induced dose-response currents and pharmacological responses that suggests the presence of $\mathrm{GABA}_{C}$ receptors in MSNs. Furthermore, there was a reduction in the effect of the $\mathrm{GABA}_{C}$ antagonist that demonstrates a lessening of this GABA receptor subtype activity as a result of mitochondria inhibition.
\end{abstract}

Keywords: 3-NP; mitochondria; HD; gaboxadol; 2-AEMP; GABAC.

\section{Introduction}

Huntington's Disease (HD) is a genetic neurodegenerative disorder originated by a gene mutation which results in the degeneration of neurons mainly in the nucleus striatum. The underlying mechanisms of degeneration are not fully understood, but experimental evidence suggests that the bioenergetics' deficit produced by mitochondrial dysfunction and oxidative stress can be a significant factor in the development and progression of HD [1-4]. Indeed, the systemic administration of toxins or mitochondrial inhibitors, such as 3-nitropropionic acid (3-NP), produces movement disorders in primates and rodents [5-9] and cell damage that resembles the neuropathology observed in patients affected by HD [10-12]. This effect occurs because GABAergic striatal projection neurons (medium spiny neurons, MSNs) are particularly vulnerable to mitochondrial dysfunction and excitotoxicity $[1,13]$. For example, $3-\mathrm{NP}$ in a concentration that produces $10 \%$ of inhibition of the succinate dehydrogenase (SDH) is capable of promoting the mitochondria permeability transition pore and stimulates $\mathrm{Ca}^{2+}$ increase, that in concert with the stimulation of glutamate receptors induces neuronal death of striatal MSNs $[14,15]$. The study of the physiological mechanisms responsible for the major vulnerability of MSNs may add to the development of therapeutic strategies, capable of lessening or stopping the neurodegenerative process and clinical manifestations. No cure for HD has been developed thus far; treatments are directed to attenuate symptomatology. 
GABAergic transmission is one of the main objectives to develop treatments to reduce excitability increase at the striatum of HD patients, because GABA release produces phasic and tonic inhibition at the MSNs. Phasic inhibition is given by receptors located at the postsynaptic sites which are low sensitivity receptors, while tonic inhibition is given by high affinity receptors normally located at extra synaptic sites. $\mathrm{GABA}_{\mathrm{A}}$ tonic mediated currents have been related with cellular protection in excitotoxicity. Therefore, tonic GABAergic inhibition has been proposed as a target for therapeutic management in HD [16-18].

Our group has demonstrated that 3-NP treatment can imitate early stages of HD [19] and alters GABAergic synapses and plasticity [20]. Also, the treatment with GABAergic agonists improves the behavior and activity of mitochondrial complexes in rodents treated with 3-NP, suggesting that GABAergic agonists exert a neuroprotective effect in instances of mitochondrial damage [21]. Additionally, GABAergic receptors undergo conformational changes that appear to protect MSNs from damage due to excitotoxicity [17]. To further the understanding of GABA receptors alterations in the early stages of HD, the objective of this study was to evaluate whether mitochondrial inhibition that mimics the early stages of HD modifies the kinetics of GABA-induced currents and pharmacology of GABAergic receptors in MSNs.

\section{Material and Methods}

All protocols and procedures employed in this study were reviewed and approved by the institutional board of bioethics (VIEP-2013-3557) and followed the national (NOM-062-ZOO-1999) and international guidelines of care and use on experimental animals.

\subsection{Animals}

Male C57BL/ 6 strain, 30-day-old mice were obtained from Harlan, Inc., México or ENVIGO RMS, México. The mice were housed in Plexiglas boxes at room temperature $\left(24-26^{\circ} \mathrm{C}\right)$ under a $12: 12 \mathrm{~h}$ light/dark cycle with free access to food and water, and assigned to a group treated with 3-NP $(15 \mathrm{mg} / \mathrm{kg}$, diluted in phosphate buffer (0.1 M PB, pH 7.4, dissolved in $1 \mathrm{~mL} / 20 \mathrm{~g})$, i.p. over 5 days) or to a control group that only received the pharmaceutical excipient $(0.1 \mathrm{M} \mathrm{PB}, \mathrm{pH} 7.4,1 \mathrm{~mL} / 20 \mathrm{~g})$ in an equal amount. 2 days after last treatment injection, the electrophysiological recordings were carried out [19].

\subsection{Reagents}

Unless otherwise stated all reagents were purchased from Sigma-Aldrich (St. Louis, MO, USA).

\subsection{Slice Preparation}

Tissue slicing and separation were performed according to previously described methods [22,23]. Dissection of the striatum was limited to the region that was rostral and dorsal to the anterior commissure to reduce contamination by the globus pallidus.

Slices were maintained between 1 and 6 hours at room temperature $\left(20-22^{\circ} \mathrm{C}\right)$ in Earle's balanced salt solution (EBSS), buffered with sodium bicarbonate $\left(\mathrm{NaHCO}_{3}\right)$, supplemented with $1 \mathrm{mM}$ pyruvic acid, $0.005 \mathrm{mM}$ glutathione, $0.1 \mathrm{mM} \mathrm{N}^{\mathrm{G}}$-nitro-L-arginine and $1 \mathrm{mM}$ kynurenic acid, and bubbled with $95 \% \mathrm{O}_{2} / 5 \% \mathrm{CO}_{2}$. The $\mathrm{pH}$ was adjusted to 7.4 with $\mathrm{NaOH}$ and osmolarity adjusted to $300 \mathrm{mOsm} / \mathrm{L}$.

After at least 1 hour of incubation, slices from the striate nucleus were prepared for enzymatic treatment. Each slice was placed in a culture chamber containing $40 \mathrm{~mL}$ of Hank's balanced salt solution (HBSS) mixed with $0.2 \mathrm{mg}$ papain (Calbiochem, San Diego CA, USA), buffered with 4-(2-hydroxyethyl)-1-piperazineëthanesulfonic acid (HEPES), bubbled with $\mathrm{O}_{2}$ and maintained at $35^{\circ} \mathrm{C}$ for $10 \mathrm{~min}$. The solution was supplemented in the same way as the EBSS.

Subsequent to enzymatic digestion, the tissue was washed with a solution of isethionate and later mechanically separated with various sizes of flame-polished Pasteur pipettes. Suspensions of cells were seeded in 35-mm polystyrene Petri dishes (Nunclon Surface, NUNC, Rochester, NY, USA) 
mounted on the recording chamber coupled to a microscope. After $10 \mathrm{~min}$ of incubation, the suspension was washed with a solution containing $140 \mathrm{mM} \mathrm{NaCl}, 23 \mathrm{mM}$ glucose, $15 \mathrm{mM}$ HEPES, $2 \mathrm{mM} \mathrm{KCl}$, $2 \mathrm{mM} \mathrm{MgCl}_{2}, 1 \mathrm{mM} \mathrm{CaCl}_{2}$ and $1 \%$ phenol red, bubbled with $\mathrm{O}_{2} \mathrm{pH}$ was adjusted to 7.4 with $\mathrm{NaOH}$ and osmolarity adjusted to $300 \mathrm{mOsm} / \mathrm{L}$ to prepare the tissue for subsequent recording using the voltage-clamp technique.

\subsection{Whole-Cell Patch-Clamp Technique}

Whole-cell voltage-clamp was used to record GABA-induced currents in neurons of the striate nucleus. Recording electrodes were pulled from borosilicate capillary tubes (1B120F-4, WPI, Sarasota, Florida, USA) with a micropipette puller (P-97, Sutter Instruments, CO, USA) and a resistance ranging from 4 to $8 \mathrm{M} \Omega$.

The internal solution consisted of $175 \mathrm{mM} \mathrm{N}$-methyl-D-glutamine (NMDG), $40 \mathrm{mM}$ HEPES, $2 \mathrm{mM} \mathrm{MgCl} 2,10 \mathrm{mM}$ ethylene glycol-bis ( $\beta$-aminoethyl ether)- $\mathrm{N}, \mathrm{N}, \mathrm{N}^{\prime}, \mathrm{N}^{\prime}$ - tetra acetic acid (EGTA), $12 \mathrm{mM}$ phosphocreatine, $3 \mathrm{mM} \mathrm{Na}_{2} \mathrm{ATP}, 0.35 \mathrm{mM} \mathrm{Na}_{3} \mathrm{GTP}$ and $0.1 \mathrm{mM}$ leupeptin, adjusted to a $\mathrm{pH}$ of 7.3 with $\mathrm{H}_{2} \mathrm{SO}_{4}$ / NMDG and 265-270 mOsm/L. The external solution consisted of $127 \mathrm{mM} \mathrm{NaCl}$, $20 \mathrm{mM} \mathrm{CsCl}, 5 \mathrm{mM} \mathrm{BaCl}_{2}, 2 \mathrm{mM} \mathrm{CaCl}_{2}, 12 \mathrm{mM}$ glucose and $10 \mathrm{mM}$ HEPES, adjusted to a $\mathrm{pH}$ of 7.4 with $300-305 \mathrm{mOsm} / \mathrm{L} \mathrm{NaOH}$ and was supplemented as appropriate with GABAergic agents. Recordings were obtained with a Multiclamp 700A voltage clamp amplifier (Molecular Devices, Foster City, CA), controlled with pCLAMP version 8 (Molecular Devices, Foster City, CA) run on a Pentium (IV, $3.20 \mathrm{GHz}$ ) computer with a Digidata 1322A interface (Molecular Devices, Foster City, CA).

Once the seal was broken, only cells with an input resistance $\left(R_{I N}\right)$ less than $25 \mathrm{M} \Omega$ were included in the study. To record GABA-induced currents the holding potential was set at $0 \mathrm{mV}$, allowing access to the chlorine-based GABA-activated current, whose equilibrium potential is about $-80 \mathrm{mV}$. Additionally, maintaining the membrane continuously at $0 \mathrm{mV}$ inactivates sodium and calcium currents. Potassium was blocked by the $\mathrm{Cs}^{+}$and $\mathrm{Ba}^{2+}$ present in the external solution.

\subsection{Drug Application}

GABA-activated currents ( $\mathrm{I}_{\mathrm{GABA}}$ ) were induced by applying the compound using a system of capillaries placed at $45^{\circ}$ with respect to each other and at a distance of 200 to $600 \mu \mathrm{m}$ from the recorded cell. One capillary contained the external solution alone (control), and the other had the external solution and 1 of 2 ligands (Figure 1). The solution was changed using solenoid valves (The Lee Company, Essex CO LFAA 1201718H) controlled by the output of the Digidata 1322A system (Molecular Devices, Foster City, CA) and a control apparatus designed in our laboratory. The ligands used were 4, 5, 6, 7-tetrahydroisoxazolo (5,4-c) pyridin-3-ol (THIP, Gaboxadol), which is an agonist of $\mathrm{GABA}_{\mathrm{A}}$ receptors that contain the $\delta$ subunit but an antagonist of $\mathrm{GABA}_{\mathrm{C}}$ receptors, the negative allosteric modulator L-655,708 (TOCRIS Bioscience, Bristol, UK) an inverse agonist of $\mathrm{GABA}_{\mathrm{A}}$ receptors containing the $\alpha_{5}$ subunit, as well as the $\mathrm{GABA}_{\mathrm{C}}$ antagonist 2-Aminoethyl methylphosphonate (2-AEMP, this compound was a gift from Dr. Lobo, University of Maryland, USA).

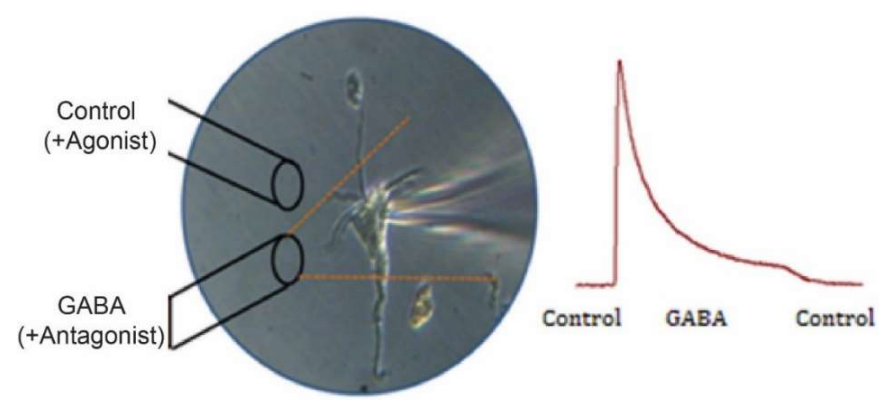

Figure 1. Application of solutions using capillaries. The application of solutions was controlled using solenoid valves; on the right of the photo, there is a representative trace of the current generated by the GABA application. 


\subsection{Electrophysiology Protocols}

Application of GABA: With a membrane holding potential of $0 \mathrm{mV}$, GABA was applied for $5 \mathrm{~s}$; the entire protocol lasted $90 \mathrm{~s}$.

Recovery protocol: This protocol was used to study the time constant for the recovery of the current to $100 \%$ after the initial application. A test pulse was delivered, followed by a quiet period increased in steps of $5 \mathrm{~s}$, at which point a second pulse was delivered. The interval between the initial pulses was $90 \mathrm{~s}$. Each pulse used a holding potential of $0 \mathrm{mV}$.

Current versus voltage (IV) protocol: Square voltage pulses were applied in steps of $20 \mathrm{mV}$ to achieve a holding potential of $-80 \mathrm{mV}$. During the pulse, GABA was applied for $5 \mathrm{~s}$. The protocol lasted for $90 \mathrm{~s}$.

Control condition: The cell was continuously perfused with the external solution using capillary 1 for the duration of the protocol, which was interrupted for $5 \mathrm{~s}$ to bathe the cell with $0.1,0.3,1,3$, $10,30,100,300$ or $1000 \mu \mathrm{M}$ GABA through capillary 2 . This experimental condition was used as the control and for the wash out to eliminate the effect of the application of the GABA antagonists.

GABA + antagonist condition: The bath was maintained with the external solution and interrupted with a cell bath with a solution for the co-application of GABA and Gaboxadol, GABA and L-655,708, or GABA and 2-AEMP.

\subsection{Statistical Analysis}

The antagonistic effect was measured as the reduction in the amplitude of the peak of the $\mathrm{I}_{\mathrm{GABA}}$ with respect to the control and wash conditions. The percent reduction was calculated as follows:

$$
\% \text { reduction }=((\delta I N E /((\delta I C+\delta I L) / 2))-1) * 100
$$

where $\delta I C$ is the GABA induced current density in the control condition, $\delta I L$ is the GABA induced current density in the wash condition, and $\delta I N E$ is the GABA induced current density in the presence of the GABA antagonist. Values are reported as the mean \pm standard error of the mean (SEM). Curve fits and graphs were generated in Origin 9.1 (Microcal Software Inc., North Hampton, MA). Data analysis was performed using analysis of variance (ANOVA) followed by a multiple comparison test with the significance set at $p<0.05$.

\section{Results}

A total of 173 cells were recorded: 150 MSNs and 23 giant interneurons. Half of the MSNs belonged to the control group and half to the group from mice treated with 3-NP. Only recorded neurons with a membrane resistance $\geq 1 \mathrm{G} \Omega$ and an input resistance $<25 \mathrm{M} \Omega$ were included in the sample.

The size of the cells was determined by measuring the cell capacitance and using a capacitance/area ratio of $1 \mu \mathrm{F} / \mathrm{cm}^{2} .95 \%$ and $98 \%$ of the neural population were MSNs whose capacitance ranged from 3 to $6 \mathrm{pF}$ (Figure S1). There was no difference in the measured capacitance in the cells of the 2 groups (Figure S1).

In each experiment, cellular viability was evaluated with a voltage ramp (from $-100 \mathrm{mV}$ to $+40 \mathrm{mV})$ lasting $300 \mathrm{~ms}$ to generate $\mathrm{Na}^{+}\left(\mathrm{I}_{\mathrm{Na}}{ }^{+}<1 \mathrm{nA}\right)$ and $\mathrm{Ca}^{2+}\left(\mathrm{I}_{\mathrm{Ca}}{ }^{2+}<100 \mathrm{pA}\right)$ currents. Cells with values lower than these were excluded from analysis.

\subsection{Recording $I_{G A B A}$}

\section{Equilibrium Potential for $\mathrm{I}_{\mathrm{GABA}}$}

The current versus voltage (IV) protocol was used to generate the $\mathrm{I}_{\mathrm{GABA}}(100 \mu \mathrm{M})$ at different voltages (Figure $\mathrm{S} 2 \mathrm{~A}, \mathrm{~B}$ ). To determine the equilibrium potential for $\mathrm{I}_{\mathrm{GABA}}$, a second-order polynomial was fit to the peak current-voltage data (Figure S2C,D). The equilibrium potential was almost the same 
for both experimental groups, but the peak current and current density was greater for the control group than for the 3-NP group evaluated at $0 \mathrm{mV}$ but these differences were not statistically significant.

\subsection{GABA-Activated Currents $\left(I_{G A B A}\right)$}

Given the changes in membrane capacitance, $\mathrm{I}_{\mathrm{GABA}}$ was normalized to obtain the peak current density as $\mathrm{pA} / \mathrm{pF}$. $\mathrm{I}_{\mathrm{GABA}}$ was evoked using different concentrations of GABA $(0.1,0.3,1,3,10,30$, $100,300$ and $1000 \mu \mathrm{M})$; the resulting plots of current density as a function of GABA concentration are shown in Figure 2A.

The peak density of $\mathrm{I}_{\mathrm{GABA}}$ in neurons of animals from the 3-NP group was compared with that of the control group (Figure 2B).

A

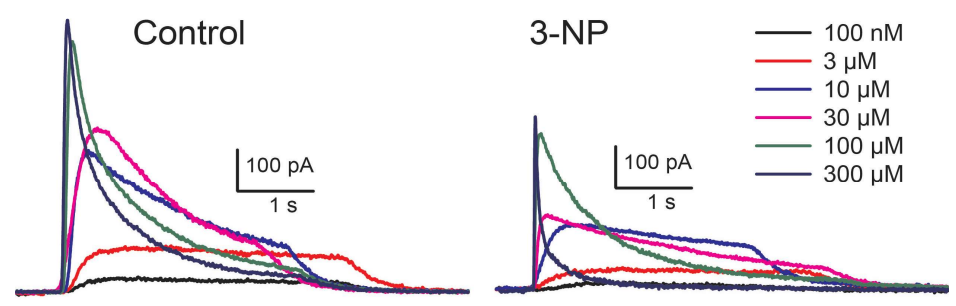

B

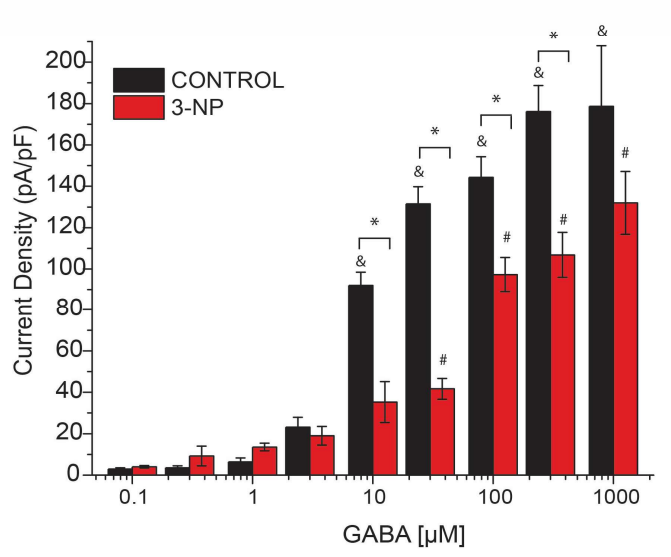

Figure 2. Dose-dependent response of GABA-activated current. (A) Representative traces of the activated current for $0.1,3,10,30,100$, and $300 \mu \mathrm{M}$ GABA from the MSNs of control and 3-NP mice. (B) Concentration dependent response to GABA is expressed as current density. The response to 10, 30, 100 , and $300 \mu \mathrm{M}$ of GABA was statistically different between control and 3-NP groups $\left(\mathrm{F}_{1,94}=6.39\right.$, $p<0.01$, two way ANOVA), the GABA induced current amplitude increased significantly in both groups by rising the concentration of GABA from $10 \mu \mathrm{M}$ for control group and from $30 \mu \mathrm{M}$ for 3-NP groups $\left(\mathrm{F}_{8,94}=26.02, p<0.05\right.$, two way ANOVA). Significant differences among GABA concentration are indicated with $\left({ }^{\&}\right)$ for control group and with $\left(^{\#}\right)$ for 3-NP groups and with a $\left(^{*}\right)$ for differences between 3-NP and control groups. Control group (black), 3-NP group (red). ${ }^{\&}, \#, * p<0.05$.

\section{GABA Dose-Response Curve in Medium Spiny Neurons}

Pharmacological effects on a population of receptors can be reflected in dose-response curves. To determine the $\mathrm{EC}_{50}$ for $\mathrm{GABA}$, a double-logistic dose-response curve was generated, resulting in $2 \mathrm{EC}_{50}$ values for each group. In the control group, $\mathrm{EC}_{50} 1$ was $13.14 \pm 5.4 \mu \mathrm{M}$ and $\mathrm{EC}_{50}$ 2 was $5.51 \pm 1.6$; in the 3-NP group, $\mathrm{EC}_{50} 1$ was $116.05 \pm 34.4 \mu \mathrm{M}$ and $\mathrm{EC}_{50} 2$ was $2.38 \pm 1.0$ (Figure 3B). These results suggest the existence of more than 1 population of receptors with different pharmacological sensitivities, where the effects of the same compound on the different populations 
are added. The 2 populations with different $\mathrm{EC}_{50}$ values are observed in the dose-response curves as different phases associated with each sigmoidal component.

Knowing the parameters for the pharmacological activities for each population with respect to the same compound, it is possible to separate 1 population from the other. We developed algorithms to differentiate the distinct parameters of the summed sigmoidal functions in Origin. This procedure is called "peeling of sigmoidal functions" and helps to distinguish the population of receptors with a low affinity for GABA (LA) from the population with a high affinity (HA) in the 2 experimental groups (Figure $3 \mathrm{~B}$ ). The $\mathrm{EC}_{50}$ of the population with high affinity to GABA was not different between the 3-NP and control groups, but a difference was found in the low-affinity populations between the 2 experimental groups (Figure 3B).

\section{A}

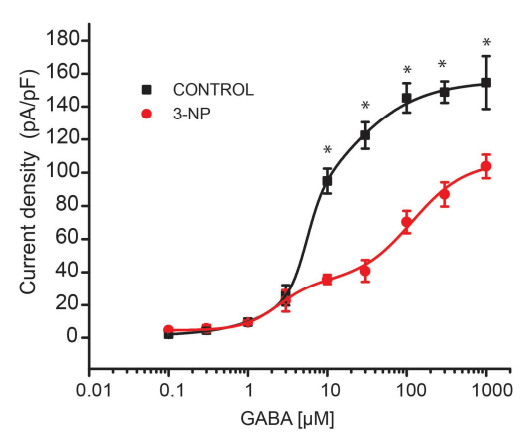

B

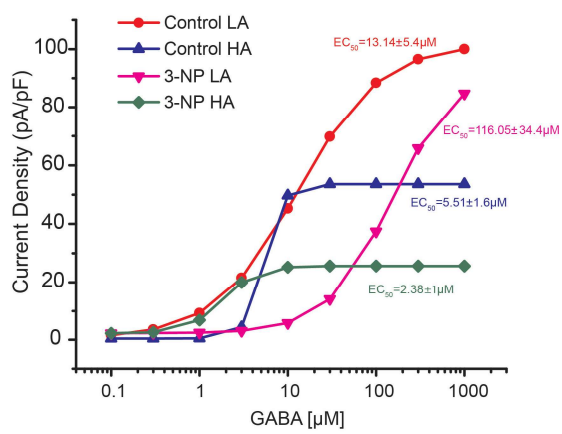

Figure 3. GABA dose-response curves. (A) GABA dependent concentrations response to $0.1 \mu \mathrm{M}$ $(n=12), 0.3 \mu \mathrm{M}(n=10), 1 \mu \mathrm{M}(n=10), 3 \mu \mathrm{M}(n=12), 10 \mu \mathrm{M}(n=12), 30 \mu \mathrm{M}(n=12), 100 \mu \mathrm{M}(n=15)$, $300 \mu \mathrm{M}(n=15)$ and $1000 \mu \mathrm{M}(n=15)$ in both experimental groups $* p<0.01$. (B) Peeling of sigmoidal functions plots to identify 2 different populations in the control group $\left(\mathrm{LA} \mathrm{EC}_{50}=13.14 \pm 5.478\right.$, and $\mathrm{HA} \mathrm{EC}_{50}=5.51 \pm 1.695, \mathrm{~F}_{7,2}=1195.24, p=0.0001$, double logistic regression) and in the 3-NP group $\left(\mathrm{LA} \mathrm{EC}_{50}=116.05 \pm 34.4\right.$ and $\mathrm{HA} \mathrm{EC}_{50}=2.38 \pm 1.09, \mathrm{~F}_{7,2}=248.69, p=0.004$, double logistic regression).

\subsection{GABA Dose-Response Curves in Giant Interneurons}

Recordings from cholinergic interneurons did not show differences in the current density versus GABA concentration used between the 2 experimental groups (Figure S3). These results demonstrate that cholinergic interneurons are not affected by mitochondrial inhibition of this model of HD.

\subsection{Kinetics of the $I_{G A B A}$}

The following parameters were analyzed to study the kinetics of $\mathrm{GABA}_{\mathrm{A}}$ receptors: steady state/peak current, time to peak and time constant (tau) of desensitization.

\subsubsection{Steady-State (SS)/Peak Current}

The steady-state to peak current ratio ranges between 0 and 1, as shown in Figure 4. From the dose-response curve, the steady state/peak current ratio shows that at low GABA concentrations $(<10 \mu \mathrm{M})$, currents generated present a desensitization of approximately $50 \%$, while at higher doses $(>10 \mu \mathrm{M})$, the desensitization is approximately $95 \%$. But the groups did not present statistical differences. 


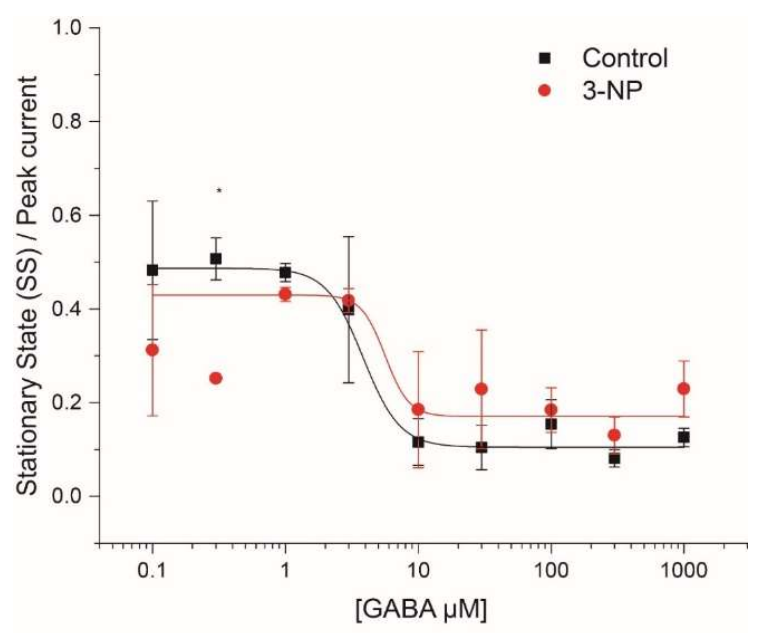

Figure 4. Steady-state versus peak GABA-activated current. The SS/peak parameter was used as a measure of GABA receptor desensitization for concentrations of $0.1 \mu \mathrm{M}, 0.3 \mu \mathrm{M}, 1 \mu \mathrm{M}, 3 \mu \mathrm{M}, 10 \mu \mathrm{M}$, $30 \mu \mathrm{M}, 100 \mu \mathrm{M}, 300 \mu \mathrm{M}$ and $1000 \mu \mathrm{M}$ in MSNs of both evaluated groups. Data Analysis showed differences in $0.3 \mu \mathrm{M}$ GABA concentration but no between groups or in the interaction $\left(\mathrm{F}_{8,17}=5.53\right.$, $p<0.001$, Two way ANOVA).

\subsubsection{Time to Peak}

The time to peak was used as a measure of the activation time of $\mathrm{I}_{\mathrm{GABA}}$. The values obtained at GABA concentrations of $10 \mu \mathrm{M}, 100 \mu \mathrm{M}$ and $1000 \mu \mathrm{M}$ were significantly faster than those obtained with $0.1 \mu \mathrm{M}, 0.3 \mu \mathrm{M}$, and $3 \mu \mathrm{M}$ of GABA but we did not find significant differences between the control and the 3-NP groups except for $10 \mu \mathrm{M}, 100 \mu \mathrm{M}$ and $1000 \mu \mathrm{M}$ (Figure 5).

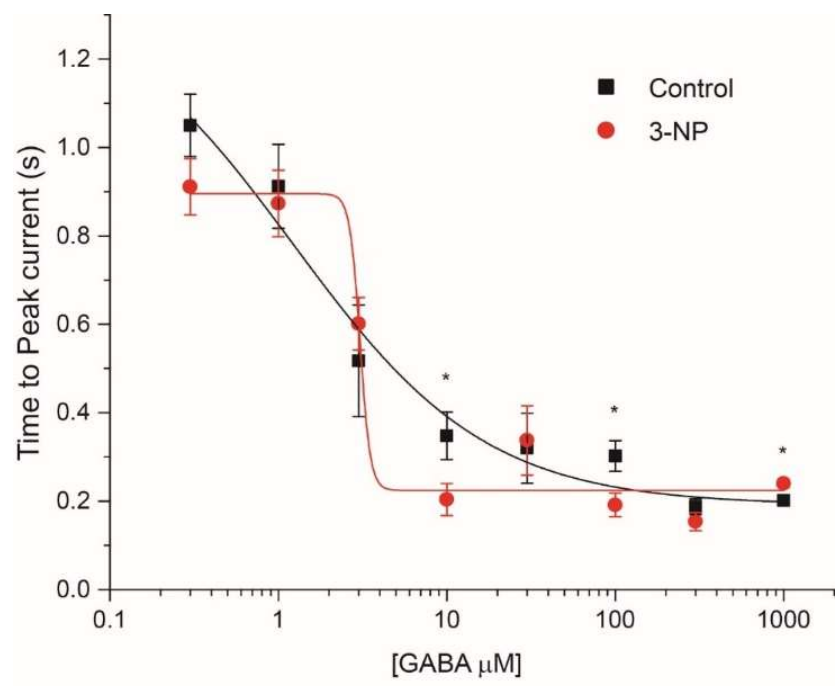

Figure 5. Time to peak of the GABA current. The activation time of $\mathrm{I}_{\mathrm{GABA}}$ was different only for GABA concentrations of $10 \mu \mathrm{M}, 100 \mu \mathrm{M}$, and $1000 \mu \mathrm{M}\left(\mathrm{F}_{7,15}=69.36, p<0.05\right.$, Two ways ANOVA $){ }^{*} p<0.05$.

\subsubsection{Time Constant of Desensitization $(\operatorname{tau}, \tau)$}

The speed and desensitization of the $\mathrm{GABA}_{\mathrm{A}}$ receptor depend on the composition of the subunits. In our experiments we only identified significant differences in the values of $\tau$ between experimental groups for the GABA concentration of $0.1 \mu \mathrm{M}$ (Table 1). 
Table 1. Time constant of desensitization.

\begin{tabular}{ccccc}
\hline & Control & \multicolumn{3}{c}{ 3-NP } \\
\hline GABA $\mu$ M & $\boldsymbol{\tau}$ ms & SE & $\boldsymbol{\tau}$ ms & SE \\
\hline 0.1 & 975.73 & \pm 254.90 & 391.70 & $* \pm 47.44$ \\
0.3 & 674.24 & \pm 133.83 & 444.63 & \pm 52.48 \\
1 & 539.43 & \pm 133.35 & 565.41 & \pm 72.35 \\
3 & 1056.66 & \pm 503.34 & 1035.37 & \pm 366.46 \\
10 & 874.02 & \pm 321.01 & 713.63 & \pm 236.11 \\
30 & 851.91 & \pm 206.72 & 601.76 & \pm 170.57 \\
100 & 957.68 & \pm 115.54 & 903.12 & \pm 104.11 \\
300 & 468.44 & \pm 63.53 & 766.92 & \pm 144.60 \\
1000 & 761.81 & \pm 330.15 & 1133.05 & \pm 148.23 \\
\hline
\end{tabular}

Table displays desensitization time constants for each GABA concentration in the experimental groups $* p<0.001$.

\subsection{Recovery of $I_{G A B A}$}

The recovery protocol described in the methodology section was used to evaluate both experimental groups. Figure 6A illustrates traces obtained for the control and 3-NP groups. The percentage of recovery of the current was plotted versus time and was fit to a first-order decaying exponential, yielding values similar for the control group and for the 3-NP group (Figure 6B).
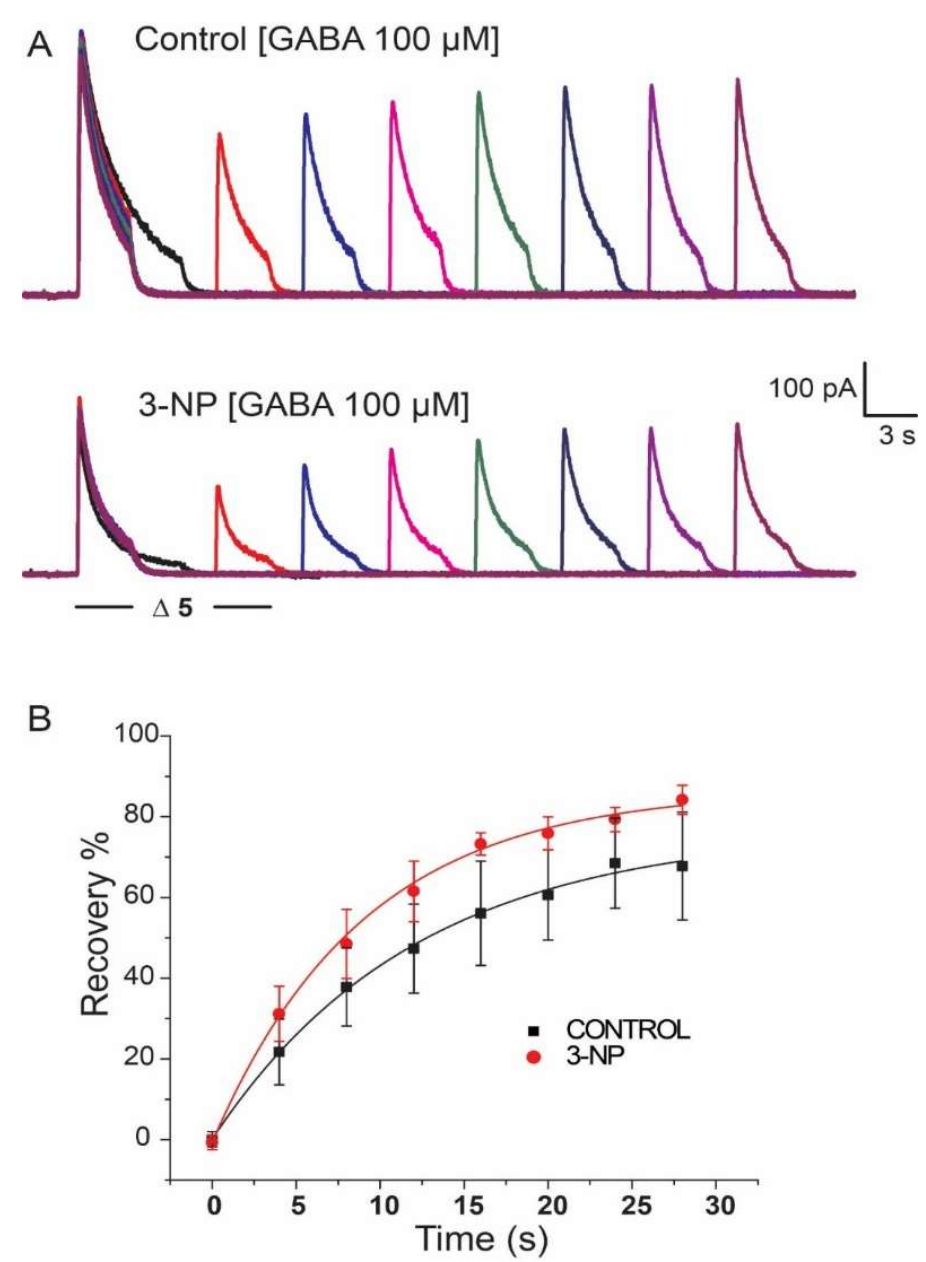

Figure 6. Recovery of $\mathrm{I}_{\mathrm{GABA}}$. (A) Representative plot of the GABA $(100 \mu \mathrm{M})$ recovery protocol for a control group neuron and for a 3-NP group neuron. (B) Plot of the percentage of current recovery versus time for the application of $100 \mu \mathrm{M}$ GABA. Recovery time for the control group was similar for the recovery time for the 3-NP group. 
Given the characteristics observed in the $\mathrm{I}_{\mathrm{GABA}}$ dose-response, we questioned the role of high-affinity and low-desensitization receptors in MSNs of our HD animal model. GABA extra synaptic receptors are known to be high affinity receptors which are sensitive to ischemic alterations and may change in degenerative disorders, and then we decided to evaluate GABA receptors with the $\alpha 5$ and $\delta$ subunits.

\subsection{Effects of the $\alpha 5$ Subunit Inverse Agonist L-655708}

The percent reduction in $\mathrm{I}_{\mathrm{GABA}}$ induced by $100 \mu \mathrm{M}$ GABA was determined in the MSNs in the presence of 3, 10, 30, 100 and $1000 \mathrm{nM} \mathrm{L-655708,} \mathrm{a} \mathrm{GABA}$ receptor $\alpha 5$ subunit inverse agonist (Figure 7). The dose-response analysis of the GABA current density in the presence of L-655708 resulted in an $\mathrm{EC}_{50}$ of $119.11 \pm 52.8$ for the control group and $\mathrm{EC}_{50}$ of $95.85 \pm 43.02 \mu \mathrm{M}$ for the 3-NP group. Figure 7A shows representative traces of the effect of L-655708 $100 \mathrm{nM}$ and $1 \mu \mathrm{M}$ on the $\mathrm{GABA}_{\mathrm{A}}$ receptors in control and in the 3-NP group. Figure 7B shows plots of the current density of the experiments with the L-655708. Note that no significant differences were found in the percent reduction of the current due to the co-application of L-655708 and $100 \mu \mathrm{M}$ GABA between the 2 groups. These results demonstrate that GABA receptors with the $\alpha 5$ subunit are not altered as a result of the damage produced by mitochondria inhibition.

A

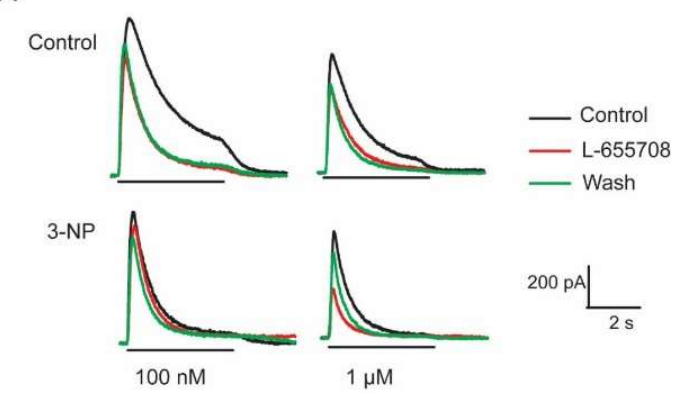

B

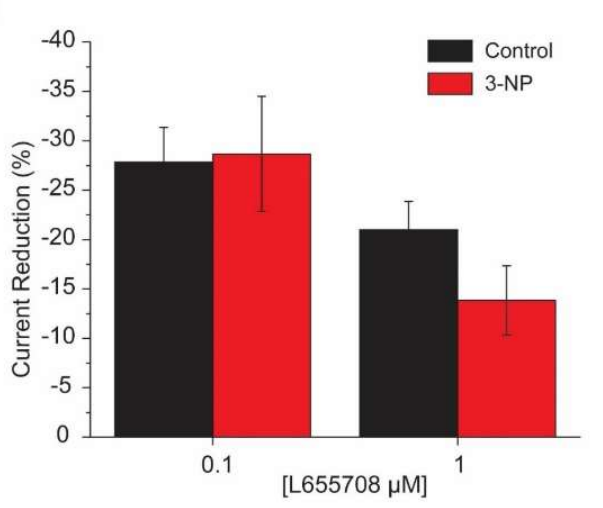

Figure 7. L-655708 effects on GABA induced current. (A) Representative traces of the current generated by GABA in the presence of $100 \mathrm{nM}$ and $1 \mu \mathrm{M}$ L-655708 in the MSNs of the control and 3-NP groups. (B) Plot of the GABA induced current reduction in the presence of two different concentrations of L-655708.

\subsection{Effects of the Gaboxadol}

The effects of Gaboxadol, an agonist of $\mathrm{GABA}_{\mathrm{A}}$ receptors with $\delta$ subunits and an antagonist of $\mathrm{GABA}_{C}$ receptors, was evaluated in the presence of $100 \mu \mathrm{M}$ GABA. Figure $8 \mathrm{~A}$ shows representative traces of these effects. Surprisingly, we observed a concentration-dependent reduction in $\mathrm{I}_{\mathrm{GABA}} \mathrm{i} n$ both evaluated groups instead of the expected increase.

The percent reduction in current in the MSNs was analyzed at 1, 10, 100 and $300 \mu \mathrm{M}$ of Gaboxadol giving an $\mathrm{EC}_{50}=15.67 \pm 1.968$ for control neurons and $\mathrm{EC}_{50}=9.81 \pm 3.562$ for neurons of the 3-NP 
group. The statistical analysis did not show significant differences between neurons in the control group versus those in the 3-NP group (Figure 8B).

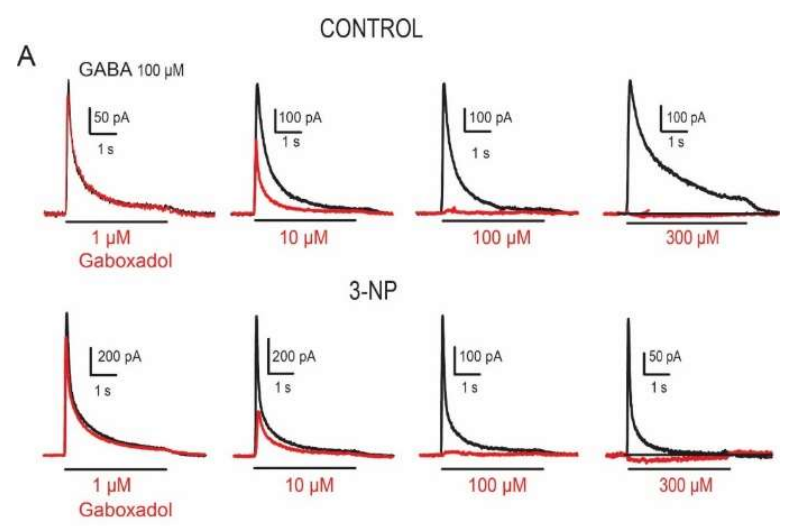

B

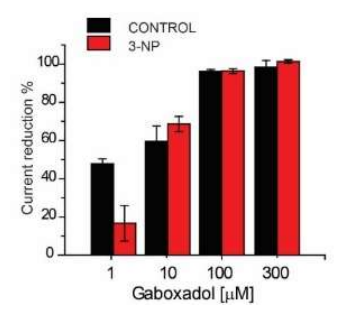

Figure 8. Gaboxadol effect on GABA induced current. (A) Representative traces of the GABA induced current $(100 \mu \mathrm{M})$ with a co-application of Gaboxadol in $1 \mu \mathrm{M}, 10 \mu \mathrm{M}, 100 \mu \mathrm{M}, 300 \mu \mathrm{M}$ in both experimental groups. (B) Plot of the GABA induced current reduction recorded from the MSNs using increasing concentrations of Gaboxadol in control and 3-NP groups.

\subsection{GABA $\mathrm{C}$ Receptors Reduction in 3-NP Group}

Pharmacological inhibition of GABA induced currents by Gaboxadol suggested the presence of $\mathrm{GABA}_{C}$ receptors, since the Gaboxadol may act on $\mathrm{GABA}_{C}$ and $\mathrm{GABA}_{A}$ receptors we opted for the specific evaluation of $\mathrm{GABA}_{C}$ function in striatal MSNs. To do that evaluation, we used the 2-Aminoethyl methylphosphonate trifluoroacetate salt (2-AEMP) a competitive $G_{A B} A_{C}$ antagonist. To see the effect of the 2-AEMP on high affinity GABA receptors we used a GABA concentration of $10 \mu \mathrm{M}$ as reported by other studies [24]. 2-AEMP reduced $\mathrm{I}_{\mathrm{GABA}}$ peak current in neurons of both; control and 3-NP-treated mice (Figure 9A); however, the reduction in the 3-NP group was significantly smaller $(-15.03 \% \pm 2.49)$ than in the control group $(-39.29 \% \pm 2.49)$, suggesting that $\mathrm{GABA}_{\mathrm{C}}$ receptors are reduced as a result of mitochondrial inhibition (Figure 9B). 


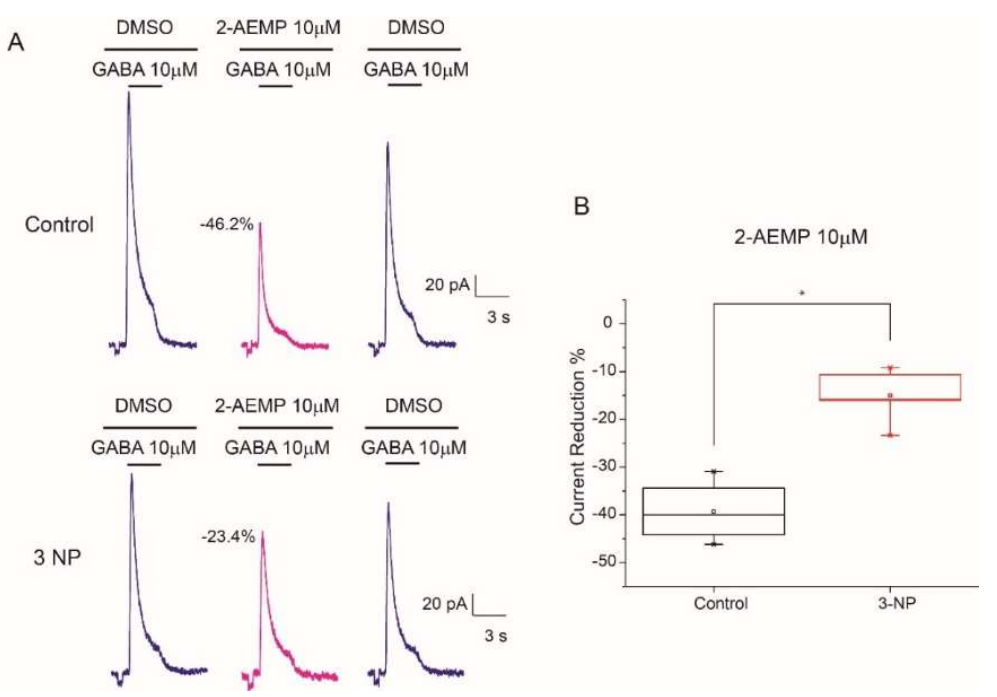

Figure 9. 2-AEMP effect on GABA induced current. (A) Representative traces of the GABA induced current $(10 \mu \mathrm{M})$ with a co-application of 2-AEMP $(10 \mu \mathrm{M})$ in Control (top) and 3-NP groups (bottom). GABA administration was co-applied with DMSO used as an excipient for 2-AEMP. (B) Box plots illustrating the current peak reduction of $\mathrm{I}_{\mathrm{GABA}}$ induced by the GABA $\mathrm{C}$ antagonist. MSNs from the 3 -NP group were significantly less inhibited by the 2-AEMP compared to control neurons $\left(t_{7}=-6.015\right.$, $p<0.001)$.

\section{Discussion}

The aim of this study was to evaluate whether mitochondrial inhibition that mimics early stages of HD modifies the kinetics of GABA-induced currents and pharmacology of GABAergic receptors in MSNs.

Our data showed that cells from the mice treated with 3-NP exhibited a reduction in the GABA gated peak current in concentrations of 10, 30, 100, 300 and $1000 \mu \mathrm{M}$. High affinity receptors did not show significant differences in the peeling of sigmoidal functions analysis. Differences were observed in the high affinity receptors as observed with concentrations higher to $10 \mu \mathrm{M}$ of GABA. No changes were observed in the stationary state and in the time to peak in most of the evaluated concentrations. The recovery of GABA current neither exhibited significant changes between groups.

We tested an antagonist (L655708) and agonist (Gaboxadol) of GABA receptors containing the $\alpha 5$ subunit which has been implicated in GABA transmission neuroprotection. The exploration of high affinity receptors with the $\alpha 5$ antagonist L- 655708 did not present differences between groups and exhibited a small reduction of the $\mathrm{I}_{\mathrm{GABA}}$ amplitude. The evaluation of Gaboxadol did not present an increase in the $\mathrm{I}_{\mathrm{GABA}}$ amplitude. On the contrary, a reduction in the $\mathrm{I}_{\mathrm{GABA}}$ amplitude was observed in a dose concentration mode. The effect of Gaboxadol on $\mathrm{GABA}_{\mathrm{A}}$ receptors varies depending on GABA subunit composition. It is a partial agonist of GABA receptors with $\alpha 1 \beta 2 \gamma 2$ and full agonist GABA receptors with $\alpha 5$ subunit, however is an antagonist of $\mathrm{GABA}_{C}$ receptors containing the $\rho 1$ subunit [25-28]. To verify the presence of $\mathrm{GABA}_{C}$ in dissociated MSNs and evaluate the role of those receptors, some experiments were carried out with the competitive $\mathrm{GABA}_{C}$ antagonist 2-AEMP, this compound reduced GABA gated current in less proportion than it did in control cells, demonstrating that these receptors were reduced as a result of mitochondria inhibition.

\subsection{MSN Capacitance Decreases as a Result of 3-NP}

The recorded neurons were identified by their morphologies, capacitances and input resistances. The capacitance of the MSNs did not significantly decrease in the group treated with 3-NP. Although the reduction in capacitance in dissociated cells is less evident than in recordings from cells in slice preparations. Our lab has demonstrated that the MSNs of mice treated with 3-NP in same concentration 
of this study, have a smaller number of spines and narrower dendrites [29]. These changes reduce the capacitance, a result also found in other animal models of HD [30,31].

\subsection{Recording $I_{G A B A}$}

The equilibrium potential for GABA was the same between the 2 groups, as well as the recovery time of the response to $100 \mu \mathrm{M}$ GABA. Interestingly, the current density was greater for neurons treated with 3-NP at the lowest GABA concentration ( 0.1 to $1 \mu \mathrm{M})$, indicating that GABA high affinity receptors increased in these group of cells, probably as compensatory response in the early stages of striatal neurodegeneration [17].

Analysis of the dose-response curve in the MSNs showed the presence of at least 2 populations of GABAergic receptors exhibiting different affinities for and efficacies in response to GABA. MSNs treated with 3-NP showed a change in $\mathrm{EC}_{50}$ of a population of receptors with low affinity, suggesting that mitochondrial inhibition modifies the expression and/or composition of the subunits of the $\mathrm{GABA}_{\mathrm{A}}$ receptor. There is experimental evidence of changes in the subunits of GABA receptors in a number of neuropathologies and in hypoxic events [32].

Administration of GABA at low concentrations $(<10 \mu \mathrm{M})$ resulted in little desensitization in the control group and 3-NP group. At higher concentrations $(>10 \mu \mathrm{M})$, both groups showed a desensitization of $95 \%$ of the current with no significant differences between the groups.

The activation time was not different between groups. Analysis of the kinetics revealed one-time constants of desensitization $\left(\tau_{1}\right)$ that was not significantly different for all GABA concentrations. Both, the speed and degree of desensitization depend on the subunit composition and they may change [33-35]. However, the lack of kinetics differences in our experimental groups was due to the fact that our animal model mimics early stages of HD and GABA responses are not damaged as they may be in advanced stages of the illness.

The giant interneurons did not show any changes due to treatment with 3-NP, neither in their capacitance nor in the kinetics of the GABA current, similar to the behavior of neurons in HD-transgenic mice [36,37]. It is not known how interneurons remain the same despite the observed changes in the spiny projection neurons in advanced stages of the illness in HD patients and animal models.

\subsection{Effect of $L-655708$}

We evaluated whether high affinity GABA receptors containing $\alpha 5$ subunit, that have been involved in neuroprotection were present in the MSNs. Our data showed that they are present but did not show significant differences in the reduction percentage of the GABA current when $100 \mathrm{mM}$ of GABA was co-applied to at different concentrations of the specific antagonist L-655708 [38], suggesting that expression of the $\alpha_{5}$ subunit of the $\mathrm{GABA}_{\mathrm{A}}$ receptor is not altered by treatment with 3-NP, as it happened in the R6/1 mouse model of HD at 6 months [18].

Because the experiments were performed in the soma of the dissociated MSNs, we cannot rule out the possibility of a change in the expression of the receptors in the dendrites. L-655708 is 50-100 times more selective for the GABA $\mathrm{A}_{\mathrm{A}}$ receptors containing the $\alpha_{5}$ subunit than for those that contain $\alpha_{1}$, $\alpha_{2}, \alpha_{3}$ and $\alpha_{6}$ and they are located mainly at extrasynaptic sites [39].

\subsection{Effect of Gaboxadol}

Gaboxadol is a partial agonist of $\mathrm{GABA}_{\mathrm{A}}$ receptors that express the $\alpha_{4}$ and $\delta$ subunits full agonist of GABA receptors containing the $\alpha_{5}[25,26,40]$; but it acts as an antagonist of GABA ${ }_{C}$ receptors which contain rho subunits [27]. We did not observe any agonistic effect of Gaboxadol when recording from the soma of dissociated MSNs. Gaboxadol acted as an antagonist to the $\mathrm{I}_{\mathrm{GABA}}$ in both the control cells and those from animals in the 3-NP group, indicating that this effect could occur through actions on the $\mathrm{GABA}_{C}$ receptors of the MSNs; these receptors are in the striatum [41], and may be able to form heteromers with $\mathrm{GABA}_{\mathrm{A}}$ in the striatum as occurs in other regions [42,43]. Still our results were unexpected, because in MSNs GABA $A$ mainly have been described [22,23]. The experiments with 
the 2-AEMP were conclusive to demonstrate that $\mathrm{GABA}_{\mathrm{C}}$ are in MSNs and they are reduced in 3-NP tissue. Indeed, a reduction in GABA $\rho 3$ subunit has also been documented in theR6/2 transgenic mice model of HD [44], supporting that $\mathrm{GABA}_{C}$ receptors are affected in HD pathology.

$G_{A B A}$ receptors have high affinity and slow desensitization to GABA and may mediate GABA responses to low GABA concentrations. They are thought to be located at perisynaptic sites and could participate in the tonic inhibition of GABA suppressing neuronal excitability, which in the presence of 3-NP and HD is increased [8].

\section{Conclusions}

Little is known of the long-term behavior and of the changes that occur in the GABAergic synapses in striatal degeneration induced by mitochondrial dysfunction. Evidence suggests that adaptive changes occur in synaptic function, and some of them can be protective to counteract the pathology $[45,46]$. Our data showed that $\mathrm{GABA}_{C}$ receptors exhibited a reduction in its function on striatal cells as a result of the mitochondria inhibition. Thus, further experiments should address the pharmacological profile and function of $\mathrm{GABA}_{C}$ receptors in the projection neurons at the striatum and in behavioral evaluations. Moreover, this information invites us to explore GABAergic function in depth in particular $\mathrm{GABA}_{C}$ receptors as a therapeutic target in striatal neurodegeneration produced by mitochondria dysfunction in HD and will help in the treatment of patients afflicted by HD.

Supplementary Materials: The following are available online at http:/ /www.mdpi.com/2076-3425/8/12/217/s1, Figure S1: Capacitance histogram, Figure S2: Reversal potential for GABA in recorded MSNs, Figure S3: Dose response of GABA in cholinergic interneurons.

Author Contributions: J.F.-H.: designed experiments, acquired data, J.A.G.-V. acquired and analyzed data, G.H.-C. acquired and analyzed data, E.N.-M. acquired and analyzed data, E.A.R.-L. acquired data, E.H.-E. conceived and designed experiments, analyzed data and wrote the paper.

Funding: This research was funded by the DGAPA-PAPIIT (IN201307) and CONACYT (81062) Grants to EHE.

Acknowledgments: Authors thank Ernesto Mendoza and Lorena Arroyo for their technical work.

Conflicts of Interest: The authors declare no conflict of interest.

\section{References}

1. Browne, S.E.; Howling, A.C.; MacGarvey, U.; Balk, M.; Bcrgvr, S.C.; Muqit, M.M.; Bird, E.D.; Beal, M.F. Oxidative damage and metabolic dysfunction in Huntington's disease: Selective vulnerability of the basal ganglia. Ann. Neurol. 1997, 41, 646-653. [CrossRef]

2. Reddy, P.H.; Shirendeb, U.P. Mutant Huntingtin, Abnormal Mitochondrial Dynamics, Defective Axonal Transport of Mitochondria, and Selective Synaptic Degeneration in Huntington's Disease. Biochim. Biophys. Acta 2012, 1822, 101-110. [CrossRef] [PubMed]

3. Mehrotra, A.; Sandhir, R. Mitochondrial cofactors in experimental Huntington's disease: Behavioral, biochemical and histological evaluation. Behav. Brain Res. 2014, 261, 345-355. [CrossRef] [PubMed]

4. Lane, R.K.; Hilsabeck, T.; Rea, S.L. The role of mitochondrial dysfunction in age-related diseases. Biochim. Biophys. Acta 2015, 1847, 1387-1400. [CrossRef] [PubMed]

5. Ludolph, A.C.; He, F.; Spencer, P.S.; Hammerstad, J.; Sabri, M. 3-Nitropropinic acid-exogenous animal neurotoxin and possible human striatal toxin. Can. J. Neurol. Sci. 1991, 18, 492-498. [CrossRef] [PubMed]

6. Beal, M.F.; Brouillet, E.; Jenkins, B.G.; Ferrante, R.J.; Kowall, N.W.; Miller, J.M.; Storey, E.; Srivastava, R.; Rosen, B.R.; Hyman, B.T. Neurochemical and histologic characterization of striatal excitotoxic lesions produced by the mitochondrial toxin 3-nitropropionic acid. J. Neurosci. 1993, 13, 4181-4192. [CrossRef]

7. Borlongan, C.V.; Koutouzis, T.K.; Freeman, T.B.; Hauser, R.A.; Cahill, D.W.; Sanberg, R. Hyperactivity and hypo activity in a rat model of Huntington's disease: The systemic 3- nitropropionic acid model. Brain Res. Protoc. 1997, 1, 253-257. [CrossRef]

8. Brouillet, E.; Jacquard, C.; Bizat, N.; Blum, D. 3-Nitropropionic acid: A mitochondrial toxin to uncover physiopathological mechanisms underlying striatal degeneration in Huntington's disease. J. Neurochem. 2005, 95, 1521-1540. [CrossRef] 
9. Liu, H.-G.; Ma, Y.; Meng, D.-W.; Yang, A.-C.; Zhang, J.-G. A Rat Model of Hemidystonia Induced by 3-Nitropropionic Acid. PLoS ONE 2013, 8, e79199. [CrossRef]

10. VonsatteI, J.P.; Nyers, R.H.; Stevens, T.; Ferrunte, R.; Bird, E.D.; Richardson, E.P., Jr. Neuropathological classification of Huntington's disease. J. Neuropathol. Exp. Neurol. 1995, 44, 559-577. [CrossRef]

11. Borlongan, C.V.; Nishino, H.; Sanberg, P.R. Systemic but not intraparenquimal administration of 3-nitropropionic acid mimics the neuropathology of Huntington's disease: A speculative explanation. Neurosci. Res. 1997, 28, 185-189. [CrossRef]

12. Walker, F.O. Huntington's disease. Lancet 2007, 369, 218-228. [CrossRef]

13. Sieradzan, K.A.; Mann, D.M.A. The selective vulnerability of nerve cells in Huntington's disease. Neuropathol. Appl. Neurobiol. 2001, 27, 1-21. [CrossRef] [PubMed]

14. Kim, G.W.; Copin, J.C.; Kawase, M.; Chen, S.F.; Sato, S.; Gobbel, G.T.; Chan, P.H. Excitotoxicity is required for induction of oxidative stress and apoptosis in mouse striatum by the mitochondrial toxin, 3-nitropropionic acid. J. Cereb. Blood Flow Metab. 2000, 20, 119-129. [CrossRef] [PubMed]

15. Mirandola, S.R.; Melo, D.R.; Saito, A.; Castilho, R.F. 3-nitropropionic acid-induced mitochondrial permeability transition: Comparative study of mitochondria from different tissues and brain regions. J. Neurosci. Res. 2010, 88, 630-639. [CrossRef] [PubMed]

16. Ade, K.K.; Jannsse, M.J.; Ortinski, P.I.; Vicini, S. Differential tonic GABA conductances in striatal medium spiny neurons. J. Neurosci. 2008, 28, 1185-1197. [CrossRef] [PubMed]

17. Santhakumar, V.; Jones, R.T.; Mody, I. Developmental regulation and neuroprotective effects of striatal tonic GABAA currents. Neurosci. 2010, 167, 644-655. [CrossRef] [PubMed]

18. Du, Z.; Tertrais, M.; Courtand, G.; Leste-Lasserre, T.; Cardoit, L.; Masmejean, F.; Halgan, C.; Cho, Y.H.; Garret, M. Differential alteration in expression of striatal GABAAR subunits in mouse models of Huntington's disease. Front. Mol. Neurosci. 2017, 10, 198. [CrossRef] [PubMed]

19. Rodríguez, E.; Rivera, I.; Astorga, S.; Mendoza, E.; García, F.; Hernández-Echeagaray, E. Uncoupling oxidative/energy metabolism with low sub chronic doses of 3-nitropropionic acid or iodoacetate in vivo produces striatal cell damage. Int. J. Biol. Sci. 2010, 6, 199-212. [CrossRef] [PubMed]

20. Nieto-Mendoza, E.; Hernández-Echeagaray, E. Dopaminergic Modulation of Striatal Inhibitory Transmission and Long-Term Plasticity. Neural. Plast. 2015, 2015, 1-15. [CrossRef]

21. Kumar, P.; Kalonia, H.; Kumar, A. Possible GABAergic mechanism in the neuroprotective effect of gabapentin and lamotrigine against 3-nitropropionic acid induced neurotoxicity. Eur. J. Pharmacol. 2012, 674, 265-274. [CrossRef] [PubMed]

22. Flores-Hernández, J.; Hernandez, J.; Snyder, G.L.; Yan, Z.; Fienberg, A.A.; Moss, S.J.; Greengard, P.; Surmeier, D.J. D1 dopamine receptor activation reduces GABA (A) receptor currents in neostriatal neurons through a PKA/DARPP-32/PPI signaling casacade. J. Neurophysiol. 2000, 83, 2996-3004. [CrossRef] [PubMed]

23. Hernández-Echeagaray, E.; Cepeda, C.; Ariano, M.A.; Lobo, M.K.; Sibley, D.R.; Levine, M.S. Dopamine reduction of GABA currents in striatal Medium-Sized spiny Neurons is mediated principally by the D1 receptor subtype. Neurochem. Res. 2007, 32, 229-240. [CrossRef] [PubMed]

24. Xie, A.; Yan, J.; Yue, L.; Feng, F.; Mir, F.; Abdel-Halim, H.; Pepperberg, D.R. 2-Aminoethyl Methylphosphonate, a Potent and Rapidly Acting Antagonist of GABAA-p1 Receptors. Mol. Pharmacol. 2011, 80, 965-978. [CrossRef] [PubMed]

25. Brown, N.; Kerby, J.; Bonnert, T.P.; Whiting, P.J.; Wafford, K.A. Pharmacological characterization of a novel cell line expressing human $\alpha 4 \beta 3 \delta$ GABAA receptors. Br. J. Pharmacol. 2002, 136, 965-974. [CrossRef] [PubMed]

26. Mortensen, M.; Ebert, B.; Wafford, K.; Smart, T.G. Distinct activities of GABA agonists at synaptic-and extrasynaptic-type GABAA receptors. J. Physiol. 2010, 588, 1251-1268. [CrossRef] [PubMed]

27. Krehan, D.; Frølund, B.; Ebert, B.; Nielsen, B.; Krogsgaard-Larsen, P.; Johnston, G.A.; Chebib, M. Aza-THIP and related analogues of THIP as GABA C. antagonists. Bioorg. Med. Chem. 2003, 11, 4891-4896. [CrossRef] [PubMed]

28. Johnston, G.A.R.; Chebib, M.; Hanrahan, J.R.; Mewett, K.N. Neurochemicals for the investigation of GABAC Receptors. Neurochem. Res. 2010, 35, 1970-1977. [CrossRef] 
29. Mendoza, E.; Miranda-Barrientos, J.; Vázquez-Roque, R.A.; Morales-Herrera, E.; Ruelas, A.; De la Rosa, G.; Flores, G.; Hernández-Echeagaray, E. Mitochondrial inhibition in vivo alters corticostriatal function and the modulatory effects of neurotrophins. Neuroscience 2014, 280, 156-170. [CrossRef]

30. Cepeda, C.; Starling, A.J.; Wu, N.; Nguyen, O.K.; Uzgil, B.; Soda, T.; Marjorie, V.M.A.; Levine, M.S. Increased GABAergic Function in Mouse Models of Huntington's disease: Reversal by BDNF. J. Neurosci. Res. 2004, 78, 855-867. [CrossRef]

31. Rocher, A.B.; Gubellini, P.; Merienne, N.; Boussicault, L.; Petit, F.; Gipchtein, P.; Jan, C.; Hantraye, P.; Brouillet, E.; Bonvento, G. Synaptic scaling up in medium spiny neurons of aged BACHD mice: A slow-progression model of Huntington's disease. Neurobiol. Dis. 2016, 86, 131-139. [CrossRef] [PubMed]

32. Hines, R.M.; Davies, P.A.; Moss, S.J.; Maguire, J. Functional regulation of GABAA receptors in nervous system pathologies. Curr. Opin. Neurobiol. 2011, 22, 1-7.

33. Bianchi, M.T.; Macdonald, R.L. Slow phases of GABA(A) receptor desensitization: Structural determinants and possible relevance for synaptic function. J. Physiol. 2002, 544, 3-18. [CrossRef] [PubMed]

34. Haas, K.F.; Macdonald, R.L. GABAA receptor subunit $\gamma 2$ and $\delta$ subtypes confer unique kinetic properties on recombinant GABAA receptor currents in mouse fibroblasts. J. Physiol. 1999, 514, 27-45. [CrossRef] [PubMed]

35. Saxena, N.C.; Macdonald, R.L. Assembly of GABA(A) receptor subunits: Role of the delta subunit. J. Neurosci. 1994, 14, 7077-7086. [CrossRef] [PubMed]

36. Graveland, G.A.; Williams, R.S.; DiFiglia, M. Evidence for degenerative and regenerative changes in neostriatal spiny neurons in Huntington's disease. Science 1985, 227, 770-773. [CrossRef] [PubMed]

37. Ferrante, R.; Kowall, N.W.; Beal, M.F.; Martin, J.B.; Bird, E.D.; Richardson, E.P., Jr. Morphologic and histochemical characteristics of a spared subset of striatal neurons in Huntington's disease. J. Neuropathol. Exp. Neurol. 1987, 46, 12-27.

38. Quirk, K.; Blurton, P.; Fletcher, S.; Leeson, P.; Tang, F.; Mellilo, D.; Ragan, C.I.; McKernan, R.M. $\left[{ }^{3}\right.$ H] L-655,708, a novel ligand selective for the benzodiazepine site of $\mathrm{GABA}_{\mathrm{A}}$ receptors which contain the $\alpha 5$ subunit. Neuropharmacology 1996, 35, 1331-1335. [CrossRef]

39. Nusser, Z.; Sieghart, W.; Somogyi, P. Segregation of different GABA(A) receptors to synaptic and extrasynaptic membranes of cerebellar granule cells. J. Neurosci. 1998, 18, 1693-1703. [CrossRef]

40. Drasbek, K.R.; Jensen, K. THIP, a Hypnotic and Antinociceptive Drug, Enhances an Extrasynaptic GABAA Receptor-mediated Conductance in Mouse Neocortex. Cer. Cortex 2006, 16, 1134-1141. [CrossRef]

41. Rosas-Arellano, A.; Machuca-Parra, A.I.; Reyes-Haro, D.; Miledi, R.; Martinez-Torres, A. Expression of GABA rho receptors in the neostriatum: Localization in aspiny, medium spiny neurons and GFAP-positive cells. J. Neurochem. 2012, 122, 900-910. [CrossRef] [PubMed]

42. Pan, Z.H.; Zhang, D.; Zhang, X.; Lipton, S.A. Evidence for coassembly of mutant GABAC rho1 with GABAA gamma2S, glycine alpha1 and glycine alpha2 receptor subunits in vitro. Eur. J. Neurosci. 2000, 12, 3137-3145. [CrossRef] [PubMed]

43. Milligan, C.J.; Buckley, N.J.; Garret, M.; Deuchars, J.; Deuchars, S.A. Evidence for inhibition mediated by coassembly of GABAA and GABA-C receptor subunits in native central neurons. J. Neurosci. 2004, 24, 7241-7250. [CrossRef] [PubMed]

44. Kumar, U.; Heer, M.; Somvanshi, R.K. Regional and subcellular distribution of GABAC rho3 receptor in the brain of R6/2 mouse model of Huntington's Disease. Neurosci. Lett. 2017, 640, 81-87. [CrossRef] [PubMed]

45. Hasbani, M.J.; Underhill, S.M.; De Erausquin, G.A.; Goldberg, M.P. Synapse loss and regeneration: A mechanism for functional decline and recovery after cerebral ischemia? Neuroscientist 2000, 6, 110-119. [CrossRef]

46. Belelli, D.; Harrison, N.L.; Maguire, J.; Macdonald, R.L.; Walker, M.C.; Cope, D.W. Extrasynaptic GABA receptors: Form, Pharmacology and Function. J. Neurosci. 2009, 29, 12757-12763. [CrossRef] [PubMed]

(C) 2018 by the authors. Licensee MDPI, Basel, Switzerland. This article is an open access article distributed under the terms and conditions of the Creative Commons Attribution (CC BY) license (http://creativecommons.org/licenses/by/4.0/). 